\section{FORTHCOMING EVENTS}

(Meetings marked with an asterisk * are open to the public.)

\section{Saturday, February 26}

School Nature STdDY UNION (at the Central Club, Y.W.C.A. Great Russell Street, London, W.C.1), at 2.30 p.m.-Thirty-eighth Annual Conference ; at 3 p.m.-Prof. W. B. R. King: "The Evidence of Fossils".

\section{Monday, February 28}

ROYAL Socterty of ARTs (at John Adam Street, Adelphi, London, W.C.2), at 1.45 p.m.-Dr. E. B. Bailey, F.R.S. : "Natural Resources SocIETY OF CHEMICAL INDUSTRY (PLASTTCS GROJP) (joint meeting SOCIETY OF CHEMICAL INDUSTRY (PLASTICS GROJP) (joint meeting
with the ASSOCIATION OF TAR DISTILLERS) (at Gas Industry House, with the ASSOCIATION OF TAR DISTILLERS) (at Gas Industry House, 1 Grosvenor Place, London, S.W.1), at 2.30 p.M.-Dr. H. Levi

BRITISH Association of CHEMISTS (NORTH-EAST SECTION) (in the Chemistry Lecture 'Theatre, King's College, Newcastle-upon-Tyne), at 5.30 p.m.-Prof. J. B. Speakman: "Protein Fibres, their Reactivity and Industrial Application" (Fifty-fourth Bedson Lecture).

Association of AUSTRIAN ENGINEKRs, Chemrsts AND ScIFNTIFIC WORKERS IN GREAT BRITAIN (at Austria House, 28 Bryanston Square, London, W.2), at 7.15 p.m.-Mr. N. J. Radinger : "Rust, Acid and Heat Resisting Steels" (in German).

\section{Tuesday, February 29}

INSTITUTION OF BRITISH AGRICULTURAL ENGLNEERS (at the Royal INSTITUTION OF BRITISH AGRICULTURA ENG
Society of Arts, John Adam Street, Adelphi, London, W.C.2), at
1.45 p.m.-Mr. Clyde Higgs : "Mechanisation of the Mixed Furm".

MANChester LITERARY AND PHILOSOPHICAL SocIETy (joint meeting with the PHYSICAI SOCIETY OF MANCHESTER and the GEOGRAPHICAI Association) (at the University, Manchester), at 5 p.m.-Dr. E. C. Bullard : "Geological Time".

ROYAL INSTITUTION (at 21 Albemarle Street, London, W.1), at 5.15 p.m.-Dr. J. Ramsbottom: "Fungi and Modern Affairs", 3. "Fungi in Hiarness"."

INSTITUTION OF Civil ENGINeERs (STRUCTURAL AND BUILDING ENGINEERING DIVISION) (at Great George Street, Westminster, Lon-
don, S.W.1), at 5.30 p.m.-Miss Letjtia Chitty: "Modern Experimental Methods in connexion with the Design of Statically Indetermintal Methods in structures".

ShEFrield METALLURGical Association (at 198 west street, Sheffield), at 6.30 p.m.-Mr. J. C. Gregory: "The Technique of Metallographic Examination".

\section{Wednesday, March I}

ROYAI SocIETy of ARTS (at John Adam Street, Adelphi, London W.C.2), at 1.45 p.m. -The Rt. Hon. the Earl De La Warr: "Flax Production in War, and its Prospects in Peace".

INSTITUTION OF EILECTRICAL ENGINEERS (WTRELESS SECTION) (at Savoy Place, Victoria Embankment, London, W.C.2), at 5.30 p.m.Mr. A. J. Maddock: "Some Applications of Thiratrons in Radio Engineering".

INSTITUTE of WELDING (at the Institution of Civil Engineers, Great George Street, Westminster, London, S.W.1) at 5.30 p.m. $\rightarrow$ Mr. Metals".

\section{Thursday, March 2}

RoYAL INSTITUTION (at 21 Albemarie Street, London, W.1), at INSTITUTE OF PHYSICS (ELECTRONIC8 Group) (in the Reid-Knox Hall, British Institute of Radiology, 32 Welbeck Street, London, W.1) at 5.30 p.m.-Dr. F. C. Toy : "Ellectron Microscope"

INSTITUTION OF ELECTRICAL ENGINEERS (at Savoy Place, Victoria Embankment, London, W.C.2), at 5.30 p.m.-Dr. A. E. W. Austen and Miss W. Hackett: "Internal Discharges in Dielectrics, their Observation and Analysis".

CHEMICAI $_{2}$ SOcietr (LeEDS AREa LoCal Section) (joint meeting with the LEEDS UNIVERSITY CHEMICAL SOCIETY) (in the Chemistry
Lecture Theatre, The University, Leeds), at 5.30 p.m. - Discussion on "The Mechanism of Oxidation-Reduction Reactions" (to be opened by Prof. H. S. Raper, F.R.S., Prof. M. G. Evans and Dr. W. A. Waters).

\section{Friday, March 3}

Physical Societr (in the Physics Department of the Inperia College, Imperial Institute Rcad, I crden, S.W.7), at 4.30 p.m.ROYAI, INSTrrution (at 21 Albemarle Street, London, W.1), at 5 p.m.-The Rt. Hon. Lord Rayleigh, F.R.S.: "Pebbles of Regular

Chemical ENGINEERING Group (joint meeting with the Grasgow SECTION OF THE SOCIETY OF CHEMICAI INDUSTRY and the INSTITUTION OF CHEMICAL ENGINEERS) (at the Royal Technical College, G]asgow), at 7.30 p.m.-Mr. Frank Broadbent: "Centrifuges"

\section{Saturday, March 4}

British Association of CHEMISTS (LONDON SECTION) (at the Chemical Society, Burlington House, Piccadilly, London, W.1), a 2.30 p.m.-Dr. T. J. Drakeley : "Training for the Chemical Industries" Gmolorists' Assocration (at the Geological Society, Burlington House, Piccadilly, London, W.1), at 2.30 p.m.-Prof. H. H. Read

\section{APPOINTMENTS VACANT}

APpurcations are invited for the following appointments on or

before the dates mentioned:
GRADUATES (3, temporary) for MATHEMaTics and ScIENCE at the GRADUATES (3, temporary) for MATHEMATICS and SCIENCE at the
Hammersmith School of Building and Arts and Crafts, Lime Grove Hommersmith School of Building and Arts and Crafts, Lime Grove, London, W.12, and a GRADUATE (temporary) for MATHEMaTICS and College Annexe, Nightingale Lane, London, S.W.4-The Education Officer (T.1), County Hall, Westminster Bridge, London, S.E.1

(March 1).

ASSISTANT MASTER IN MATHFMatios AND ScInNon in the Junior Technical School-The Principal, Royal Technical College, Salford 5 , Lancs. (March 1).

DIRFCTOR OF THE IMPERIAI AGRICULTURAL RESEARCH INSTITUTE, Government of India-The Ministry of Labour and National Service, Central (Technical and Scientiflc) Register, Advertising Section, Alexandra House, Kingsway, London, W.C.2 (quoting Reference No. O.N.F. 2080A) (March 1).

RESIDENT ExGINEER (location, Northern Ireland), to take charge of Construction Work in connection with an important Power Station extension and High Voltage Transmission Lines, Switching Stations, etc.-The Ministry of Labour and National Service, Central (Technical and Scientiflc) Register, Advertising Section, Alexandra House, King way, Iondon, W.C.2 (quoting Reference No. D.759.XA) (March 4). ASSISTANT IN THE HORTICULTURAL DEPARTMENT, with practical spraying operations and supervise the proper cultivation of orcharding -The Chief Executive Offlcer, Hereford War Agricultural Executive Committee, 4 St. John Street, Hereford (March 5).

Assistant IIECTURER IN THE MiNing DEPaR'ment of the North Staffordshire Technical College-The Clerk to the Governors, Town Hall, Hanley, Stoke-on-Trent (March 6).

EXECUTIVE ENGINBers, Grade IV, for the Nigerian Government Public Works Department - The Ministry of Iabour and National Service, Central (Technical and Scientific) Register, Advertising Section, Alexandra House, Kingsway, London, W.C.2 (quoting Reference No. E.773A) (March 6).

IRRIGATION ENGINEER by the Government of Northern RhodesiaThe Ministry of Labour and National Service, Central (Technical and Scientific) Register, Advertising Section, Alexandra House, Kingsway, London, W.C.2 (quoting Reference No. E.784A) (March 8).

way, London, W.C.2 (quoting Reference No. E.784A) (March 8).

PHYSICIST-The Registrar, University College, Hull (March 9). SENIOR DIETICIAN (woman, temporary) by the Department of
Health for Scotland-The Ministry of Labour and National Service, Health for Scotland-The Ministry of Labour and National Service,
Appointments Office, 5 Rothesay Terrace, Edinburgh 3 (March 11). Appointments Office, 5 Rothesay Terrace, Edinburgh 3 (March 11). PRINCIPAI-The Clerk to the Governors,
College, Newport, Shropshire (March 18).

Profissor of Mechanroal ENaINEERING in the Benares Hindu University Engineering College-The Secretary, Institution of Mechanical Engineers, Storey's Gate, St. James's Park, London, S.W.1. March 18).

COMMISSIONS IN H.M. Forces (a limited number) will be granted to candidates who are University-trained Biologists, preferably men with some experience of malaria or entomology-The Ministry of Register, Advertising Section, Alexandra House, Kingsway, London, W.C.2 (quoting Reference No. ONF.2057A) (March 18).

UNIVERSITY CHAIR OF ANATOMY tenable at St. Mary's Hospital Medical School-The Academic Registrar, University of London, c/o Richmond College, Richmond, Surrey (March 20).

WAYNFLETE PROFESSORSHIP OF METAPHYSICAI PHILOsophy-The Registrar, University Registry, Oxford (April 13).

PROFESSORSHIP OF ENGINEERING ScIENOE-The Registrar, University Registry, Oxford (April 30).

DIRECTOR OF THE INSTTTUTE OF MEDICAL AND VETERINARY SCIENCE, Adelaide-The Agent-General and Trade Commissioner for South Australia, South Australia Honse, Marble Arch, London, W.1 (May 31). TEACHER (part-time) OF ANIMAL PHYSIOLOGY in the Department of Biology $=$ Th

ASSISTANT LECTURER (temporary) in AGRICULTURAL CHEMISTRYThe Registrar, The University, Reading.

\section{REPORTS and other PUBLICATIONS \\ (not included in the monthly Books Supplement)}

\section{Great Britain and Ireland}

Imperial Agricultural Bureaux. Photoperiodism in the Potato. By C. M. Driver and J. G. Hawkes. Pp. 36. (Cambridge: Imperial Bureau of Plant Breeding.) 2s. $6 d$.
The Place of Science in China. By Yap Pow-Meng. Pp. 24. (London : China Campaign Committee.) 6d. Rules for Examinations and Institution of Mechanical Engineers. Rules for Examinations and
for Submission of Theses. Pp. 16. Supplement to Rules for Examinafor Submission of Theses. Pp. 16. Supplement to Rules for Examina-
tions and for Submission of Theses. Pp. 16. K(London : Institution of Mechanical Engineers.)

\section{Other Countries}

Universidad Nacional de La Plata: Publicaciones de la Facultad de Ciencias Fisicomatematicas. Serie $3:$ Publicaciones especiales, No. 23 (No. 169): Sanemiento Urbano en la Republica ArgentinaProvisión de agua $\mathrm{y}$ desagós urbanos. Por Prof. Everisto Artaza. Segunda Parte: Desagües urbanos, Cuaderno No. 1 : Centralizacion de los servicios de obras sanitarias; desagüe cloacal ; naturaleza del liquido cloacal ; bases de calculo ; lugares de vertimiento. Pp. 118. (La Plata : Universidad Nacional de La Plata.) 4 dollars. [171 Report of the Anglo-American Caribbean Commission to the Governments of the United States and Great Britain for the Years 1942-1943. mission ; London : Crown Agents for the Colonies.) $3 d$. [17] 